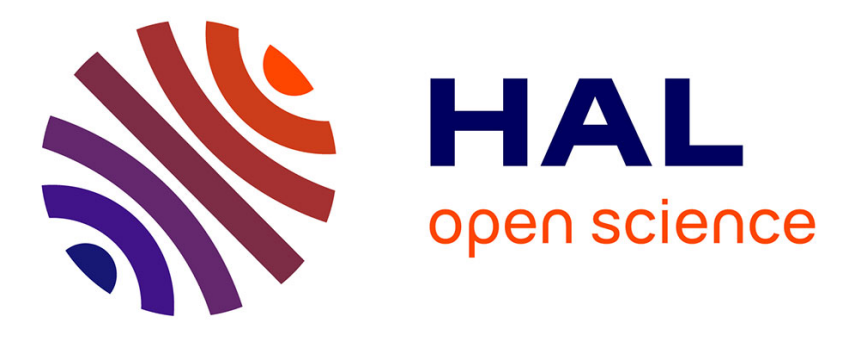

\title{
Policy analysis in French local government
}

Alain Faure, Emmanuel Négrier

\section{To cite this version:}

Alain Faure, Emmanuel Négrier. Policy analysis in French local government. Charlotte Halpern; Patrick Hassenteufel; Philippe Zittoun. Policy Analysis in France, The Policy press, pp.119-135, 2017, 9781447324218. 10.1332/policypress/9781447324218.003.0007 . halshs-01667336

\section{HAL Id: halshs-01667336 \\ https://shs.hal.science/halshs-01667336}

Submitted on 3 Jan 2018

HAL is a multi-disciplinary open access archive for the deposit and dissemination of scientific research documents, whether they are published or not. The documents may come from teaching and research institutions in France or abroad, or from public or private research centers.
L'archive ouverte pluridisciplinaire HAL, est destinée au dépôt et à la diffusion de documents scientifiques de niveau recherche, publiés ou non, émanant des établissements d'enseignement et de recherche français ou étrangers, des laboratoires publics ou privés. 


\title{
SEVEN
}

\section{Policy analysis in French local government}

\author{
Alain Faure and Emmanuel Négrier
}

The subject of the present chapter attempts to 'deconstruct' the French territorial question and demonstrate that territorial policy analysis can break free from the limitations imposed by the primarily 'statist' conceptual framework in which it has hitherto been viewed. In the first section of the chapter, we indicate the scale and nature of the present political and administrative territorial structures and comment also on the paucity of academic research work on this subject. In the second section, we highlight the main changes in the territorial framework of policy building, through an evolution from vertical to horizontal dialectic of powers and capacities. In the third section we discuss territorialisation, as the results of a double process. On the one hand, the role of ideas in territorial policy building; on the other hand, the dynamics of differentiation that put the French model into question. Thus, focusing on policy analysis in French local policies in a global comparative perspective - sheds light on the huge challenge it causes for the coherence of 'national models'. As in other countries, local policies in the French context are simultaneously influenced by globalisation and decentralisation, opening new scenes for vertical and horizontal interactions toward the provision of public goods and service.

\section{An old, dense and underestimated territorial administration}

The structures of French territorial government are notoriously complex. ${ }^{1}$ Many of its contradictions and paradoxes can be traced back to its origins in the French Revolutionary and Napoleonic period when the much-desired tabula rasa was put into operation to destroy and even to eliminate the memory of the traditional, often millennial, territorial structures. And yet, for all its rationalist features, the new structures could scarcely avoid or conceal new and long-lasting conflicts, concerning different meanings as well as applications of concepts such as 'popular sovereignty', ('direct democracy' or versions of the 'general will'), 'federalism' (compared with 'Jacobinism'), plus conflicting theories of representativeness and electoral practice, and, above all, the emergence of the 'nation' - as the paramount unitary organisational structure which led Napoleon (particularly when faced with foreign wars) to settle the arguments by streamlining the administrative system, with an overwhelming stress on 'top-down' rather than 'bottom-up' processes

For the following century and a half, this basic structure of French politics and administration went largely unchallenged, at least until after the Second World 
War when a new generation of young planners started to highlight the dangers of Paris et le désert français. Motivated no doubt by a desire to resuscitate economically and socially many of the run-down and neglected provinces as part of post-war European regeneration, this strong desire for territorial regeneration became a central thrust of government policy under the Fifth Republic, particularly with the setting up of a devoted body: the Land Development and Regional Action Delegation (Délégation à l'Aménagement du Territoire et à l'Action Régionale (DATAR)) in 1963. In less than 30 years, this largely successful injection of economic vitality into many parts of France had run its course, and, in the postMitterrand years, emphasis has passed to a questioning of the more essentially political functionality and efficacy of the complicated local and regional political structures which have emerged (or survived or - worse still - thrived through bureaucratic accretion), raising many questions concerning present policies and the politics surrounding them.

The sheer density of French territorial administration is much greater than the European average. In the three-tiered system of territorial government into which the structure is normally divided, it is the basic unit of the 'commune' which reveals the most startling diversity. With 36,767 communes, of which 32,000 have less than 2,000 inhabitants, France alone counts for more than 40 per cent of the total number of 'municipalities' in the European Union. This makes the use of this basic essential unit of limited value in functional normative terms. In order to counter the obvious disparities created by this communal fragmentation, French political forces have regularly encouraged intercommunal cooperation, and this has led to the creation of a second local 'unit': intercommunalité. This level, slowly but inexorably, has been 'institutionalised', given specific tasks, including powers of taxation, with its own officials elected by universal suffrage, and its own administration. This level of government now counts for 2,133 institutions. Of these 11 are called metropoles (representing large urban conurbations) with a further 238 'inter-communal communities' in urban zones and 1,884 in rural zones, some of which remain small (less than 5,000 inhabitants). Parallel to these institutions which are called 'Public Establishments for Intercommunal Cooperation' (EPCI), there are other bodies, without tax-raising powers, whose role is to fulfil certain (often technical) tasks. These latter are called 'intercommunal syndicates' (numbering 13,402 in 2015) and it has been the desire of successive governments since the 1990s to somehow 'merge' them into the first intercommunal category (Kerrouche, 2012). We are not there yet!

Of the two 'higher' levels of territorial structures, the division of France into 'départements' was enacted in the first year of the Revolution (with the clear intention of breaking the political and cultural power of the old provinces) and Napoleon confirmed the departments' 'top-down' function with the state appointment of a 'prefect' to each department. The Fifth Republic has seen, however, a major reduction in the powers of the prefect and, particularly in the 1980s, increasing power has been accorded to the departmental conseils which mainly control local social policy. Threatened by developing institutions 'above' 
and 'below' it, the département is the real phoenix of French administration, often rising from the ashes because of strong support for it in the Senate and its effective control over the implementation of social policy, redistributive aspects of local solidarity and questions of transport (Négrier and Nicolas, 2011). It is the département which is the crucial level at the intersection of urban and rural zones. Its electoral system, direct universal suffrage at the canton level, tends to reinforce the weight of rural zones and has recently been reformed, giving birth, in 2015, to a unique two-round majority election of dual male/female candidates.

The modern 'regions', only date from 1964. While traditionally the weakest link in French territorial administration (dating back no doubt to the revolutionaries' fear of the power of the old provinces) the regions have progressively advanced in recent years in political importance and agenda-setting policy-making (Barone, 2011). Their main thrust concerns economic development, education and higher education and research, but also general territorial infrastructures. One very recent development (2014-15) has been the (hasty) reduction in the number of regions from 22 to 13 (excluding the five overseas regions), a 'reform' that reveals the underlying paradox in attitudes to territorial government. Clearly intended to save money by cutting out duplication of services at a time of general economic retrenchment, the reform nonetheless officially aspires to create more powerful regions, which can exist and thrive on a supra-national European level. To take one example, the disparity between official aim and actual achievement is exemplified in the amalgamation of Languedoc-Roussillon and Midi-Pyrénées in the south of France. This new region is more than twice the size of Catalonia, its neighbour in the north-east of Spain. But its consolidated budget comes to less than 10 per cent of the Generalitat, its Catalonian institutional equivalent (Négrier, 2015).

This highlights the general problem - the relationship of the local and regional resources (transfers from the central state plus limited tax-raising powers) to their gradually increasing spheres of competence (resulting from the several waves of decentralisation reforms particularly since the 1980s) and the corresponding decline in direct central state territorial administration (Biland, 2012). It is true that both the areas of competence and the resources have increased considerably, to the extent that in 2012 local and regional services employed 1.8 million agents, or 34 per cent of total public employment in France.

Table 7.I: Levels of territorial administration in France and associated expenditure

\begin{tabular}{|l|l|l|}
\hline Collectivity & Number & Total expenditure 2012 (in €billions) \\
\hline Communes & 37,767 & 26 \\
EPCI & 2,133 & 39.58 \\
\hline Départements & 100 & 71.35 \\
\hline Regions & 26 & 27.92 \\
\hline
\end{tabular}

Source: personal extrapolation from Ministry of Interior figures, 2014[[167]] 
Increasing range of competences, growing human and financial resources, enhanced legitimation through the application of universal suffrage - all these would suggest a greater focus on territorialité in the overall political study and analysis of French public policy. And yet strangely, the opposite seems to be the case. A perusal of the content of the Revue Française de Science Politique in recent years shows that any emphasis on the crucial importance of local and territorial concerns in French policy studies remains a rarity. A similar analysis of the content of the journal French Politics since 2010, which could serve as a barometer of the extent to which the French territorial model is recognised internationally, gives sparse results (one single article deals with decentralisation policy under the Hollande presidency (Cole, 2014)) but without analysing the mechanisms or other specificities of the French case; there are comparative studies integrating France in general social policy (MacDaniel, 2014) or the evolution of the welfare state (Simonet, 2014) but with no consideration of the territorial aspects of these subjects.

Perhaps the reason for this neglect is the enduring prevalence of the historical 'hierarchisation' of French political values inferred above: 'top-down' has a tendency to concentrate on the top. Localised nuances tend to get lost, and simply obfuscate the international comparisons that emerge more clearly when state models are not clouded by niceties of 'local' differences, which can easily be relegated to what Freud dismissed as the 'narcissism of minor differences'. But if this marginalisation of the territorial issue applies to political science analyses of French public policy and action (Douillet et al, 2012), French territoriality nonetheless figures prominently in the English-speaking publications devoted to urban, metropolitan and regional policies. An analysis of the content of the International Journal of Urban and Regional Research, of the Journal of Urban Affairs or of Regional and Federal Studies shows that France not only has its place in the international comparisons made but also that the French 'exceptionalism' (often implicit in the 'state' comparisons), is no longer so evident. Once we move away from the national framework and put the focus on local configurations (regions, metropoles, districts), then 'national cultural factors' fade into the background, giving place to fruitful differentiations within the same national context (for example: Lyon/Marseille, or Brittany/Ile-de-France) and (dispensing with national borders entirely) facilitating very useful interterritorial comparisons (Brittany/Galicia or Lyon/Barcelona).

\section{Vertical and horizontal transformations}

The historically 'verticalist' perspective, referred to above, needs further analysis, before demonstrating the extent to which it has been superseded by increasing 'horizontalist' policy impulsions. 'Horizontal' does not imply that the horizons are the very limited ones of localist autonomy but also include distant horizons, thus giving a freer rein to international connections as well as international comparisons, leading to what we propose as a new paradigm of territorialisation. 
The 'local' is in any case a relative term. Mediation of ideas and practices can take place at various levels with various horizons (particularly at the metropolitan level).

\section{The verticalised 'local' and questioning the 'top-down' norm}

The traditional vertical dialectic certainly dominated French territorial politics in the early, Gaullian, years of the Fifth Republic. And the paradigms which were current in the 1970s and 1980s, if trying to move away from the simple 'top-down' model, sought to identify points of equilibrium or of tension between the centre and the periphery. Work on 'régulation croisée' (Grémion, 1976), in attempting to locate such intersecting areas of tension, did indeed amount to a critique of the normative discourse (often framed in juridical terms) which reduced territorial politics simply to that of enacting state policy (Alliès, 1980). Nonetheless, local powers were still essentially 'heteronomous', that is, dependent on ideological and practical norms pertaining to the decision-making apparatus of the state. The experiments carried out in certain major cities and other local projects were only exceptions to the rule (Jobert and Sellier, 1977, 215). This 'top-down' vision was also more or less shared by geographers, sociologists and economists who were interested in questions of local government. Research on urban planning (Lojkine, 1972), on the city (Castells and Godard, 1974[[161]]; Lefebvre, 1973) or even on socio-economic relations on a global scale, all tend to question any normative central/local binary division - such a dichotomy is refuted as a false equality (Dulong 1978), with localism seen as a false identity (Sfez, 1977). Neomarxist or other overall systemic orders do not need to lay stress on the 'local'.

Political science, however, focuses, on the tension at the territorial level between the elective and the bureaucratic elements, leading to interesting variations from any simple pattern, but all tending in the 1970s to be viewed in relation to a 'central' norm, the supposed coherence of which remained intact (Mabileau, 1972). Gradually, however, this was to change. Exceptions to the rule multiplied, and with the French cumul des mandats (the holding by politicians of several local or national mandates simultaneously), 'power politics' in some areas could no longer be dismissed as small-time local politics of peripheral interest. There were also cultural/political territorial manifestations (Lenclud, 1986) specific to certain areas (Corsica, Languedoc, Brittany, for example). The analyses of these cases, taking their differentiation from any national norm as a starting point, highlight their socio-economic heterogeneity and the tenuous link of these to national political integration (Jobert, 1977). Clearly, the top-down vertical and juridical model had become an inadequate tool for satisfactory analysis.

\section{The horizontal dialectic and international and interdisciplinary dimensions}

It was at the beginning of the 1980s that the first major decentralisation movements seriously called into question the adequacy of the vertical dialectic. This was also a period when a generation of political scientists became more open to constructive 
dialogue with other social scientists (particularly geographers, economists and sociologists) in focusing on the territorial factor affecting social and political issues. The ensuing controversies favoured the emergence of a more horizontal conception of notions such as urban government (Borraz, 1998; Jouve and Lefevre, 1999), governance (John, 2001; Leresche, 2001), territorialised political exchange (Négrier, 1998), the public/private relationship (Le Galès, 1997) and also subsidiarity (Faure, 1998). These perspectives brought into play factors which had been ignored in the top-down/Jacobin approach.

In the case of political sociology, in particular, such a reorientation of focus is the key to a quite different approach to ascertaining what constitutes the essence of localised politics (Briquet, 1997; Sawicki, 1997). Some of the work follows up on older studies, in monograph form, of how politics itself and power relations are constructed at the very basis of human behaviour (Lagroye, 1972[[162]], for example). These types of analysis, are close to political anthropology, bringing ethnology 'back to French soil' (Abélès, 1989; Pourcher, 1995). The local voice is no longer just a sort of 'state ventriloquist' (Mabileau, 1993). Socio-historical work on politics and administration reveal all that the bureaucratic mentality owes to the emergence, in small towns, of a particular social group and its basic need to establish institutional routines (Dumons et al, 1997). Other studies suggest that public policy has developed, earlier and more effectively, policies that have subsequently become an essential component of the new social contract. For example, the decisive entry of women into local and regional governments, as well as the reform of departmental elections (Troupel, 2017) contrasts with the erratic implementation of national parity laws (Troupel, 2013). Apart from representation issues, it was also at the local level that the first women's rights policies were forged, of which no one today disputes the centrality in contemporary democracy (Mazur and McBride, 2006). It becomes very clear in this sort of work that questions concerning the specificity of local space, legitimacy, social influence and local circumstances and motivations are more important factors than whatever regulations, procedures and party ideas are imposed by Paris.

In the case of the predominant 'vertical' dialectic, we observed that 'top-down' does not mean that all horizontal interactions were excluded (for example deals made between the prefect and the influential 'notables' in a particular department). In a similar way, the new emphasis on basic localism does not mean that other variables are not also at play, factors such as economic competition, territorial 'benchmarking', Europeanisation, the weight of private interests - all these factors, invoked in the 1990s, mean that we should not retain any simplistic romantic vision of what local autonomy really means. The change of perspective rather reflects a rejection of the post-Napoleonic juridical and rationalist organisational dogmatism, and its replacement by a renewed (and largely international) interest in institutional analysis (Hall, 1993; Hall and Taylor, 1996) as well as new reflections on the meaning of 'governance' (Jessop, 1997; Marks, 1996) and on the workings of an 'urban régime' (Harding, 1994). It should also be noted that regional analysis is increasingly viewed in comparative terms (Keating and Loughlin, 1996; Jeffery, 
1997; Le Galès and Lequesne, 1997; Négrier and Jouve, 1998). Metropolitan questions have also moved away from a strictly national/top-down interpretation towards focus on debates (reform vs public choice for example) which date back a long time in English-language research (Woods [[159]], 1958; Ostrom et al, 1961).

These analytical models and concepts, such as 'governance', 'urban regimes', 'new regionalism', 'new institutionalism' - recently imported from Englishlanguage publications - are not accepted wholesale as a coherent block without a discriminating assessment of each term by the French academic community. Urban governance is one of the clearest examples of the different variants of meaning revealed (Jouve and Lefêvre, 1999; Lorrain, 2000; Gaudin, 2002; Le Galès, 2002). Besides, other more continental imports have also had an impact on French thinking about territorial politics. This is notably the case with the Italian writings on industrial districts grouped around Carlo Trigilia (Trigilia, 1986; Ritaine, 1989; Benko and Lipietz, 1992) and on political exchanges (Pizzorno, 1997[[163]]; Ceri, 1981). These writings have also helped us to question the hypothesis of the specific radical nature of the French case, and lead us to consider French territoriality in comparative terms alongside other examples. The whole territorial question is not about simply applying preconceived sets of rules or central algorithms; rather, it opens up further questions, both empirical and theoretical, about the meaning of public action and hence about the very raison d'être of territorial policies (Arnaud et al, 2005).

\section{An example. Lessons from the regionalisation of policy capacities in three policy domains: education, transport, training}

The results of the management of these areas by the regions is, in the opinion of experts from each of them, especially noteworthy, given the initial capacity of the regions. Not only the means that have been devoted to them have greatly exceeded their investments consented before by the state through its central management, but they have affected technicians, managers and elected officials who no longer have any need to envy the professionals' territorial administration of the state. This professionalisation, which was initially inspired by the know-how developed by civil servants, themselves transferred from the state, is no longer due to them: the regional councils have become, especially in management positions and sector steering, particularly attractive for more graduate and younger administrators (Bachelet, 2006). However, this professionalisation has developed not against the state but in broad partnership with it. This is what Thierry Berthet finds in the area of vocational training policies, beyond the differences affecting, region by region, socio-economic structures of the country, or even the way politicians do politics with such policies (Berthet, 20I I). The same assessment can be found for regional transport policies, for which Sylvain Barone showed that once the regional professionalisation of these policies was observed, these policies not only differed because of the topography of an area, but because of former policies in the area, which necessarily constrained some of the choices ahead. They also differed because of distinct forms of politicisation of this policy area throughout different regions. To illustrate, in a region such as the Languedoc-Roussillon, Barone notes that one vice president of the Regional Council from 
2004 is not only a former Communist Party leader, former Minister of transportation but also a former railwayman, very sensitised to the maintenance of secondary lines and not just an apostle of speed railway. Alongside more material factors, this has a clear influence on the regional policy guidelines on the subject. In education, we draw similar lessons: a) a strong involvement of institutions in quantitative terms, with a level of investment in the construction of school facilities far higher than what the state spent in it, and at a faster pace; b) professional management in partnership with state that, in this area, has retained the management of personal and educational programmes; c) a relative differentiation of educational policies across regions, less according to a global ideology (left against right politics and policies) than the way politicians considered educational policies within their own prospects of political legitimacy (Dupuy, 20II). We can take the example of some policy tools implemented during a period - between 2004 and 2014 - where almost all regions were managed by French left governments. A regulation indeed considered as 'leftist' (the provision of school books to children according with resource conditions, that is, positive discrimination) was often preferred generalised free[[168]], more 'rightist' in its political orientation. Similarly, if early in their management of academic competence, the left-wing regional governments were more reserved than those belonging to the right wing about private education funding, this ideological 'marker' has almost disappeared over time.

Basically, the regionalisation experience of public policies led to some paradoxes: implemented by politicians, it has largely depoliticised; in sectors full of ideology and collective imagination, ideas into action have defused rather than confirmed hopes or fears; expertise, less autonomous than shared with the authorities of different levels, here leads to disappointment: the ideas it produces dissolve the ideological content of public policies.

\section{The emergence of a new paradigm of territorialisation}

At the heart of these questions, there lies a question of scale. The horizontal against the vertical has to be re-examined in the light of the changing nature and the growing dimensions of territorial politics. New ideas are permeating the new territorialisation processes - more levels of expertise, suitable to each different local context.

\section{A political inversion}

The clearly discernible movement towards both further decentralisation and also towards Europeanisation has led to an inversion of tendencies, with a repoliticisation of the state and a depoliticisation and professionalisation of territoriality. There has been a change of scale, both political, administrative and spatial, with a move to transfer a great number of public services to the intercommunal level. At the same time, the relations between the different scales have also undergone transformation (Faure et al, 2007). The territorial 
authorities now take on a growing proportion of what is still called 'welfare state' activities, now including social, educational, housing and cultural policies, with the state playing a more distant role, often resorting to contractualisation (Epstein, 2004[[164]]) and placing greater reliance on market forces rather than directly attributing responsibility for, and exercising direct control over, specific activities. The result of this is that local elites are more professionalised and better equipped (and with more funding). The idea of the state as master of public policy is replaced by local governments, with their new attributions, developing their own expertise, taking more management decisions as well as more control over policy (Borraz and Négrier, 2007). We should note that this inversion means that the state cannot remain aloof from or be impervious to local politics/policies (as it did in the early Fifth Republic) and this brings us back to the more fluid interactions between central and local government during the Third and Fourth Republics (Le Lidec, 2001).

\section{Territorial ideas in action}

Does this shifting of the centre of gravity of public policy imply new constraints and a change in the set of paradigms pertaining to the discourse of territorial government? This is the subject of much discussion between scholars. Local districts cannot themselves arrogate, unilaterally, the expression of their own political 'world'. Ideas have to be more generalised in their origin than that and the border between the public and private influences is difficult to draw. Taking the 'urban' question as an example, the word of the state professionals on this subject is now diluted by the more diffuse and variegated expertise expressed by local public bureaucracies, by circles of expertise emerging from the mixed economy, from consultancy agencies and international bodies (Cadiou, 2005). It is true that the essential plurality of this new world will not prevent the emergence of dominant discourses. This plurality clearly constitutes one of the most marking current territorial evolutions. [[169]] For example, one observes a certain standardisation in the production of ideas on 'urban projects' (Pinson, 2005), but the acceptance of this standardisation remains relatively limited, given the strong variation in argument from one locality to another and the important restructuring changes that are underway.

There were of course in the past distinctive political 'visions' which were rooted in certain areas of France. One thinks of 'municipal socialism' which was a powerful vector of partisan identification of public policy in certain areas (Lefebvre 2006). One thinks also of other 'markers' of leftwing municipal policy, such as 'cultural action' (Négrier 2003) or 'social housing' policies (Maurin, 2003[[165]]; Donzelot, 2006). In a certain way, it is paradoxically the decline of these 'great ideals' which has opened the way for the new expression of territorial action. This turning point of institutional reform of urban government can be illustrated by analysing the two forms of public action, diametrically opposed, which structure current local government debate along the lines of reform versus public choice. 
The first word (reform) implies tackling the new problems of urbanisation by creating new institutions which, in their scope and potential targets, will adequately deal with the new scale of urban problems (Wood, 1958[[159]]). The problem here is that no two urban conglomerations are remotely the same (Aix/Marseille is fundamentally different from a 'Greater Paris' or a 'Greater Grenoble'). Whereas the second phrase (public choice) implies that institutional fragmentation, entailing little new bureaucratic structures, leaves the field open to fiscal competition and competing services between communes, intending thereby to improve the efficacy of local government through 'customer/residents' choice (Ostrom et al, 1961).

What lessons can be learnt from these dilemmas? Above all that ideas must take concrete form at the urban and metropolitan levels themselves. Ideas only receive lukewarm endorsement when they have been thought up elsewhere. Ideas originating in the very place of their implementation will stand a better chance of being well and truly implemented. The setting up of an urban conglomeration, for example, has to face directly concrete problems of specific kinds: the type of representation for participating communes in the new cooperative body (Le Saout and Madoré, 2004); the effectiveness of their public policies (Négrier, 2005[[166]]); fairer ways of tax redistribution (Rousseau, 2004) and above all the problem of justifying (through a new public discourse) the existence of a new level of territorial government by a clear demonstration of the need for sharing (public transport costs, school provision, social housing, cultural facilities, and so on). Even the virtually new word 'métropole' impedes, by its recent - and sometimes ambiguous - meaning, the development of a discourse which can be impassioned and convincing.

\section{The variables of local differentiation}

The territory has ceased to be 'heteronomous', to become a sphere in which political interests, the differing logics of sectors, professional expertise and civil society's expectations, come together in a unique combination. This dynamic of differentiation is as far removed as possible from what remains of the 'Jacobin' (or Napoleonic) requirement for a unified national 'territory', designed like a classical French garden.

When having to arbitrate priorities, the regional, departmental and metropolitan administrations can no longer treat small differences as narcissistic distractions from the big picture, as in the early days of decentralisation. Local objectives and satisfaction are the primary concern. Dossiers are no longer easily categorised in nationally unified rational terms and multiple types of expertise must constantly be tested, evaluated and re-evaluated. This new form of public action, that has to be reflected also in national and international regulations, has recently been likened by the political scientist Pierre Muller to the coming together of three tectonic plates, a metaphor (albeit a potentially cataclysmic one) for the interaction of the play of market forces, the exigencies of the 'public space' and the traditional 
dirigisme (even if much reduced) of the state (Muller, 2015). These are the forces to be reconciled in each large urban area.

Two variables must constantly be taken into account in reconciling these three factors in our way of studying territories. The first is of a cultural socio-historical nature and concerns the weight of a location's specific past, that is, the depth, values and circumstances which condition the socio-cultural proclivities and the choice of options of the actors concerned. Comparative studies show that power, authority, institutions and democracy are not thought of in the same way, even if the stakes are the same, depending on whether one is recounting the common good in Madrid, Barcelona, Naples, Milan, Marseille, Nantes, Frankfurt or Munich. Each urban region has its own 'dependency path' of institutions and values which produce quite different public actions, even within the same national space. The second variable is more materialist and is also topographic. Depending on the location, for example in a mountainous or maritime area, in a dense or relatively sparsely populated area, the territorial location does not point to the utilisation of the same political instruments.

For the analyst, whether as an engaged expert or a distanced observer, taking these two variables into account poses complicated problems of method and conceptualisation. In the nascent French research devoted in recent years to urban and regional governments, these imponderables have been translated into a series of new challenges: opening up new frontiers for public action (Mevellec, 2008), leading to irreversible changes in our conception of political power (Ben Mabrouk, 2006), creating new discursive narratives to fit the metropolitan pattern (Tomàs, 2012), assessing the impact of the rise of regional governments on social fragmentation (Dupuy, 2011), and reflecting on how local elected officials are invested with new missions of political mediation (Faure, 2015). In France, as elsewhere, the rise in power of metropolitan areas and of regions suggests the emergence of a democratic differential in the sense that there will be in future powerful territorial ways of producing order and enunciating meaning. This new equation is thrust into the very heart of the research agenda in political science and suggests bridges to connect several interpretations and conceptual frameworks hitherto considered as competing and irreconcilable. To the brave accomplishments of 'new public management' or of 'public choice' can now be superposed a whole motley of hypotheses which echo the analytical innovations sometimes qualified as turning points (territorial, narrative, linguistic, emotional, participative and so on). The perspectives opened up by all this can make one a little giddy, for they link the 'big questions' concerning power and political legitimacy to our ability to see these questions through new scientific paradigms.

\section{Conclusion}

Local government and territorial policies have changed over the past 30 years. They contribute to transforming political analysis itself, suggesting new objects, but also new epistemological challenges. Thus, the three perspectives we've 
highlighted (professionalisation, pluralisation, differentiation) offer social scientists unprecedented challenges in France, although often better established in other European countries.

The first perspective - the professionalisation of local policies - requires analysts to produce models more aware of territorial configurations. It leads to paying more attention to ground research (less theoretical, more empirical) and to new links with other scientific disciplines (geography, history, law, anthropology).

The second perspective - the pluralisation of actors - implies a renewed work on local narratives and discourses. It would be tempting to only consider the functional issues of multi-layered management, as generally understood in terms of overcrowded policy making. But territorial governance challenge is less technical than symbolic and semantic. This pluralisation means at first the crisis of the great and abstract narrative on general interest (Faure, 2007): a double crisis both in terms of membership and in terms of efficiency in the everyday political life of cities and regions.

The third perspective - territorial differentiation - leads to a double and especially critical issue in France. The first is political and economical: producing knowledge on the conditions of a 'positive differentiation' (Négrier, 2010) that combines fiscal, legal and philosophical prospects. Here, the surrender of the territorial equality myth is only the starting point of a huge project: the invention of territorial equity. The second issue questions local identity. Behind this term, extremely opposed conceptions of social and spatial diversity can be found. Between territorial identity evoked in active strategies of diversity and that of essentialist neo-regionalism, there is a tremendous chasm. The Catalan experience, as well as those of Lombardy and Scotland, or the issues related to migration in contemporary Europe show that these controversies must be asked[[170]]. Here, the role of experts is fundamental: experts who invite us to understand all claims of identification but to be wary of any pretension to identity.

These three perspectives highlight the extent to which local policy analysis is now confronted by a crucial issue: to go beyond its 'natural' tendency to produce specialised diagnostics and develop an original perspective about a political/policy model of democracy both influenced by standardisation and differentiation. This double dialectics (politics/policy; standard/difference) has more to offer than the ritual opposition between institutionnalisms and culturalisms. And the French case, much more acquainted with standards, national institutions and politics, should be the country for assessing differences, regional and policy contrasted influences.

\section{Note}

1 The French adjective territorial, in an administrative sense, like its derivative territorialité, tends to cover all tiers of government up to but not including the central state.

\section{References}

Abélès, M. (1989) Jours tranquilles en 1989, Paris: Odile Jacob. Alliès, P. (1980) L'invention du territoire, Fontaine: Presses universitaires de Grenoble. 
Amin, S. (1973) Le développement inégal: Essai sur les formations sociales du capitalisme périphérique, Paris: Éditions de Minuit.

Arnaud, L., Le Bart, C., Pasquier, R. (2005) 'Déplacements idéologiques et action publique: Le laboratoire des politiques territoriales', Sciences de la société 65, 3-7.

Bachelet, F. (2006) 'Sociologie, formation et carrière des hauts fonctionnaires territoriaux', Annuaire des collectivités locales 26(26)[[149]], 99-113

Barone, S. (2011) Les politiques régionales en France, Recherches Politiques, Paris: La Découverte.

Ben Mabrouk, T. (2006) Le pouvoir d'agglomération en France: Logiques d'émergence et modes de fonctionnement, Paris: L'Harmattan.

Benko, G., Lipietz, A. (1992) Les régions qui gagnent. Districts et réseaux: les nouveaux paradigmes de la géographie économique, Paris: Presses universitaires de France.

Berthet, T. (2011) 'La régionalisation de la formation professionnelle', in S. Barone (ed) Les politiques régionales en France, pp. 51-64, Recherches Politiques, Paris: La Découverte.

Biland, É. (2012) La fonction publique territoriale, Repères/Sciences PolitiquesDroit, Paris: La Découverte.

Borraz, O. (1998) Gouverner une ville: Besançon,1959-1989, Rennes: Presses universitaires de Rennes.

Borraz, O., Négrier, E. (2007) 'The end of French Mayors?', in J. Garrard (ed) Heads of the Local State in Past and Present, Basingstoke: Palgrave Macmillan.

Briquet, J.-L. (1997) La tradition en movement: Clientélisme et politique en Corse, Paris: Belin.

Cadiou, S. (2005) 'Vers une action urbaine "moderniste": Les effets du discours des experts savants', Sciences de la société 65, 9-27.

Ceri, P. (1981) 'Le condizioni dello scambio politico', Quaderni di Sociologia 4, 640-63.

Cole, A. (2014) 'Not saying, not doing: Convergences, contingencies and causal mechanisms of state reform and decentralisation in Hollande's France', French Politics 12(2), 104-35.

Donzelot, J. (2006) Quand la ville se défait, Paris: Le Seuil.

Douillet, A.-C., Faure, A., Halpern, C., Leresche, J.-P. (2012) L'Action publique locale dans tous ses États: Différenciation et standardisation, Paris: L'Harmattan.

Dulong, R. (1978) Les régions, l'Etat et la société civile, Politiques, Paris: Presses universitaires de France.

Dumons, B., Pollet, G., Saunier, P.-Y. (1997) Les élites municipales sous la IIIème République: Des villes du Sud-Est de la France, Paris: Centre national de la recherche scientifique (CNRS).

Dupuy, C. (2010) Politiques publiques, territoires et inégalités: Les politiques régionales d'éducation en France et en Allemagne (1969-2004), PhD thesis, Paris: IEP de Paris.

Dupuy, C. (2011) 'Y a-t-il de la politique dans les politiques régionales d'éducation?', in S. Barone (2011) Les politiques régionales en France, pp. 65-84, Paris: La Découverte. 
Faure, A. (ed) (1998) Territoires et subsidiarité, Logiques Politiques, Paris: L'Harmattan.

Faure, A. (2007) 'Une nouvelle critique territoriale?', in A. Faure and E. Négrier (ed) Les politiques publiques à l'épreuve de l'action locale, pp. 275-83, Paris: L'Harmattan.

Faure, A. (2015) 'Les passions de l'élu local, du notable au médiateur', Histoire@ Politique: Politique, culture, société 25[[150]].

Faure, A., Leresche J.-P., Muller P., Nahrath S. (eds) (2007) Action publique et changements d'échelles: Les nouvelles focales du politique, Paris: L'Harmattan.

Garraud, P. (1983) 'Le recrutement des maires en milieu urbain: Esquisse de typologie' Pouvoirs 24[[151]], 29-44.

Gaudin, J.-P. (2002) Pourquoi la gouvernance?, La bibliothèque du citoyen, Paris: Presses de Science-Po.

Ghorra-Gobin, C. (2004) 'L'étalement de la ville américaine: Quelles réponses politiques?', Esprit 3-4, 145-59.

Grémion, P. (1976) Le pouvoir périphérique: Bureaucrates et notables dans le système politique français, Paris: Seuil.

Hall, P. (1993) 'Policy paradigms, social learning and the state', Comparative Politics 25(3), 275-96.

Hall, P.A., Taylor, R.C.R. (1996) 'Political science and the three new institutionalisms', Political studies 44(5), 936-57.

Harding, A. (1994) 'Urban regimes and growth machines: Towards a cross-national research agenda', Urban Affairs Quarterly 29(3), 356-82.

Jeffery, C. (1997) The Regional Dimension of the European Union: Towards a Third Level in Europe?, London: Frank Cass.

Jessop, B. (1997) 'Capitalism and its future: Remarks on regulation, government and governance', Review of International Political Economy 4(3), 561-81.

Jobert, B., Sellier, M. (1977) 'Les grandes villes: Autonomie locale et innovation politique', Revue Française de Science Politique 27(2), 205-27.

Jobert, B. (1977) 'Bureaucraties sociales et planification locale', Annuaire de l'Aménagement du territoire, vol 8, pp. 237-50, Fontaine: Presses universitaires de Grenoble.

John, P. (2001) Local Governance in Western Europe, London: Sage.

Jouve, B., Lefevre, C. (1999) 'De la gouvernance urbaine au gouvernement des villes? Permanence et recomposition des cadres de l'action publique en Europe', Revue Française de Science Politique 49(6), 835-53.

Jouve, B., Négrier, E. (2008) 'La sécession métropolitaine: Analyse comparée franco-américaine', in M. Camau, G. Massardier (eds) Les régimes politiques revisités, Paris: Khartala.

Keating, M., Loughlin J. (1996) The Political Economy of Regionalism, London: Frank Cass.

Keil, R. (2000) 'Governance restructuring in Los Angeles and Toronto: Amalgation or secession?', International Journal of Urban and Regional Research 24(4), 758-81. 
Kerrouche, E. (2012) 'Bilan de l'intercommunalité à la française', Revue française d'administration publique, 141[[153]], 37-53

Le Galès, P. (1997) 'Quels intérêts privés pour les villes européennes?' in A. Bagnasco, P. Le Galès (eds) Villes en Europe, pp. 231-54, Paris: La Découverte.

Le Galès, P. (2002) Le retour des villes européennes, Paris: Presses de Science Po[[160]].

Le Galès, P., Lequesne, C. (1997) Les paradoxes des régions en Europe, Paris: La Découverte.

Le Lidec, P. (2001) Les maires dans la République: L'association des maires de France, élément constitutif des régimes politiques français depuis 1907, thesis, Paris: Université de Paris 1, Panthéon-Sorbonne.

Le Saout, R., Madoré, F. (2004) Les effets de l'intercommunalité, Rennes: Presses universitaires de Rennes.

Lefebvre, H. (1973) Espace et politique, Paris: Anthropos.

Lenclud, G. (1986) 'De bas en haut, de haut en bas, le système des clans en Corse', Etudes Rurales 101-2,[[154]] 137-73.

Leresche, J.-P. (2001) 'Gouvernance et coordination des politiques publiques', in J.-P. Leresche (eds) Gouvernance locale, cooperation et légitimité: Le cas suisse dans une perspective comparée, pp. 29-65, Paris: Pédone.

Lojkine, J. (1972) La politique urbaine dans la région parisienne, Paris: Mouton.

Lorrain, D. (2000) 'Gouverner les villes: Questions pour un agenda de recherche', Pôle, ud, 13, 27-40.[[155]]

Lowery, D. (2001) 'Metropolitan governance structures from a neoprogressive perspective', Swiss Political Science Revue 7-3, 130-6.

Mabileau, A. (1972) Les facteurs locaux de la vie politique nationale, Paris: Pedone.

Mabileau, A. (1993) A la recherche du 'local', Paris: L'Harmattan.

MacDaniel, S. (2014) 'Post-crisis social democratic policy capacity in France and the United Kingdom: A lesson from the globalisation and social democracy debate', French Politics 12(4), 283-309.

Marks, G. (1996) 'European integration from the 1980's: State-centric v multilevel governance', Journal of Common Market Studies 34(3), 341-78.

Mazur, A., McBride, D. (2006) 'The RNGS data set: Women's policy agencies, women's movements and policy debates in western post-industrial democracies', French politics 4(2), 209-36

Maurin, E. (2004) Le ghetto français. Enquête sur le séparatisme social, Paris: Seuil.

Mevellec, A. (2008) La Construction politique des agglomérations au Québec et en France, Laval: Presses de l'Université de Laval.

Muller, P. (2015) 'Une théorie des cycles d'action publique pour penser le changement systémique', in L. Boussaguet, S. Jacquo, P. Ravine (eds) Une 'French touch' dans l'analyse des politiques publiques?, pp. 405-35, Paris: Presses de Sciences Po.

Négrier, E. (1998) 'Échange politique territorialisé et intégration européenne', in R. Balme, A. Faure, A. Mabileau (eds) Les nouvelles politiques locales: Dynamiques de l'action publique, pp. 111-34, Paris: Presses de Science Po. 
Négrier, E. (2007) 'Penser les changements d'échelle territorial: Institution, dynamiques sociales et politiques métropolitaines', in A. Faure, J.-P. Leresche, P. Muller, S. Nahrath (eds) L'action publique à l'épreuve des changements d'échelle, Paris: Presses de Sciences Po.

Négrier, E. (2010) 'La différenciation positive', in J.C. Nemery (ed) Quelle nouvelle réforme pour les collectivités territoriales françaises?, pp. 315-24, Grale, Paris: L'Harmattan.

Négrier, E. (2015) 'Réforme territoriale: Le pire n’est pas sûr', NectArt [[156]]1, 60-7.

Négrier, E., Jouve, B. (1998) Que gouvernent les régions d'Europe?, Logiques Politiques, Paris: L'Harmattan.

Négrier, E., Nicolas, F. (2011) 'Cumbersome inheritance or democratic lever: The department at the center of French territorial concerns', in H. Heinel, X. Bertrana (eds) The Second Tier of Local Government in Europe: Provinces, Counties, Départements and Landkreise in comparison, pp. 73-89, Londonv: Routledge.

Ostrom, V., Tiebout, C., Warren, R. (1961) 'The organisation of government in metropolitan areas: A theoretical inquiry', American Political Science Review 55[[157]], 831-42.

Pinson, G. (2005) 'l'idéologie des projets urbains', Sciences de la société 65, 29-51. Pizzorno, A. (1977) 'Scambio politico e identità collettiva nel conflitto di classe', in C. Crouch, A. Pizzorno (eds) Conflitti in Europa, pp. 407-33, Milan: Etas Libris. Pourcher, Y. (1995) Les maîtres de granit: Les notables de Lozère du XVIII'me siècle à nos jours, Paris: Plon.

Ritaine, E. (1989) 'La modernité localisée? Leçons italiennes sur le développement regional', Revue Française de Science Politique 39(2), 154-78.

Rousseau, M.P. (2004) La nouvelle architecture fiscale locale et les enjeux d'intégration et de développement économique des territoires, Rapport CEIL, pour le Ministère de l'Intérieur, Paris: Université Paris XII.

Sawicki, F. (1997) Les réseaux du parti socialiste. Sociologie d'un milieu partisan, Paris: Belin.

Sfez, L. (1977) L'objet local, Paris: Christian Bourgois.

Simonet, D. (2014) 'The convergence of the British and French models of capitalism', French Politics 12[[158]], 1-21.

Tomàs, M. (2012) Penser métropolitain ? La bataille politique du Grand Montréal, Québec: Presses de l'Université du Québec.

Trigilia, C. (1986) Grandi partiti e piccole imprese: Comunisti e democristiani nelle regioni a economia diffusa, Bologne: Il Mulino.

Troupel, A. (2013) 'Entre consolidation et remise en cause: Les tribulations de la loi sur la parité (2000-2010)', Modern and Contemporary France 21(February), $17-36$

Troupel, A. (2017) 'Élus', in N. Kada, R. Pasquier, C. Courtecuisse, V. Aubelle (eds) Dictionnaire encyclopédique de la décentralisation, pp. 483-9, Paris: BergerLevrault 
Policy analysis in French local government

Wood, R. (1958) 'The New Metropolis: green belts, grass roots or Gargantua', American Political Science Review 52, [[159]] 108-22. 